This article is licensed under the Creative Commons Attribution-NonCommercial 4.0 International License (CC BY-NC) (http://www.karger.com/Services/OpenAccessLicense). Usage and distribution for commercial purposes requires written permission.

\title{
Uncommon Location of Purpura Fulminans: Case Report and Literature Review
}

\author{
Sahar Hasan Alsharifa Abdullah Al-Omair ${ }^{b} \quad$ Fedaa Andijani $^{c}$ \\ ${ }^{a}$ Alnoor Specialist Hospital, Makkah, Saudi Arabia; ${ }^{b}$ King Saud University, Riyadh, Saudi \\ Arabia; ${ }^{C K i n g}$ Abdul Aziz University, Jeddah, Saudi Arabia
}

\section{Keywords}

Purpura fulminans - Disseminated intravascular coagulation - Uncommon location of purpura fulminans - Nose

\section{Abstract}

Purpura fulminans is a critical, mostly fatal, thrombotic syndrome that requires urgent intervention. Purpura fulminans is an acute purpuric rash characterized by coagulation of the microvasculature, which leads to purpuric lesions and skin necrosis. In this report, we present a rare case of an adult patient who was admitted with rapidly forming purpura fulminans in an uncommon location.

(C) 2020 The Author(s)

Published by S. Karger AG, Basel

\section{Introduction}

Purpura fulminans is considered one of the fatal thrombotic disorders that requires immediate diagnosis and management. It is an acute purpuric rash characterized by coagulation of the microvasculature, which leads to purpuric lesions and skin necrosis. Purpura fulminans is rapidly progressive and is often accompanied by disseminated intravascular coagulation 
and circulatory collapse. It can be inherited or acquired and can occur in neonates, children, and adults. There are three forms of this disease with a classification scheme based on the triggering mechanism: inherited abnormalities of protein $\mathrm{C}$ or other coagulation systems, acute infectious purpura fulminans, and idiopathic [1]. In this report, we present a rare case of an adult patient who was admitted with acute infectious purpura fulminans in an uncommon location.

\section{Case Report}

A 75-year-old male was presented to the emergency department with a decreased level of consciousness associated with a skin lesion over the nose for 1 day. He had a past medical history of myelofibrosis.

Dermatological examination showed a nonblanching violaceous ecchymosis with localized central early skin necrosis on the tip of the nose (Fig. 1a, b).

Our initial differential diagnosis included purpura fulminans, warfarin-induced skin necrosis, levamisole-contaminated cocaine-induced necrosis or vasculitis, lupus pernio, and cryoglobulinemia.

There was no history of exposure to warfarin or levamisole-contaminated cocaine, and the cryoglobulin test was negative. Other laboratory results are shown in Table 1.

The blood cultures grew methicillin-resistant Staphylococcus aureus.

The combination of clinical presentation and laboratory results led to the diagnosis of purpura fulminans.

On the second day of the clinical course, skin lesions progressed rapidly to a sharply delineated full-thickness necrosis over the patient's entire nasal region (Fig. 2a, b). His clinical course was complicated by disseminated intravascular coagulation, which required the transfusion of blood products, along with ventilatory support for hypoxic respiratory failure and inotropes for controlling the acute heart failure. He also developed acute renal failure, which required hemodialysis. By the end of the second day, the patient had passed away.

\section{Discussion}

The term "purpura fulminans" was first used in the late 1800s to describe a syndrome of extensive purpura in severely ill patients, usually children, in the setting of an acute or convalescent infection [1]. Purpura fulminans is a rare, life-threatening condition characterized by disseminated intravascular coagulation, with extensive tissue thrombosis and hemorrhagic skin necrosis. Purpura fulminans that is caused by heterozygous protein $\mathrm{C}$ deficiency with venous thromboembolism usually does not have disseminated intravascular coagulation as a component of its pathogenesis [1].

Purpura fulminans begins with erythema, which develops irregular central areas of blueblack hemorrhagic necrosis. The distribution of purpura fulminans lesions may be different according to the underlying pathogenesis. Purpura fulminans in severe sepsis is typically developed in the distal extremities and progresses proximally, or it appears as a generalized or diffuse purpuric rash affecting the whole body surface. In reviewing the literature, there are 
very few cases of purpura fulminans that occur over the nose. All of them are summarized in Table 2 [2-8]. A case of purpura fulminans that occurred over the nose was first described in 1986 [2]. It was a case of rhinocerebral mucormycosis for an infant with streptococcal sepsis and purpura fulminans [2]. In 1989, Har-El et al. [3] described a case of purpura fulminans of the head and neck secondary to pneumococcal sepsis in a splenectomized patient. In 2006, Duteille et al. [4] reported a case of a 5-year-old boy who underwent subtotal amputation of the nose after meningococcus-induced purpura fulminans. Urushidate et al. [5] performed nose and upper lip reconstruction on a 48-year-old male patient, following left cerebellopontine angle tumor excision, who suffered from purpura fulminans after sepsis due to Klebsiella pneumoniae. Pei Chia Eng et al. [6] published a very challenging case of purpura fulminans which involved the tip of the nose and was caused by Capnocytophaga septicemia following a dog bite. The patient was diagnosed by a blood film [6]. The most recent case of purpura fulminans that involved the nose was published in February 2017 [7]. It was one of the rare causes of purpura fulminans associated with a paraneoplastic syndrome in a patient with mesothelioma who was receiving chemotherapy [7]. All the previous cases of purpura fulminans have involved the nose, in addition to the distal extremities. However, in contrast to all previous studies, our case presented with isolated purpura fulminans over the nose. To our knowledge, the only published case of a similar presentation was caused by septic abortion [8].

\section{Conclusion}

Purpura fulminans is a life-threatening thrombotic disorder that requires immediate diagnosis and management. It is rare to present with an isolated lesion to one site of the body, as discussed in this case. An isolated necrotic skin lesion over the nose does not exclude the diagnosis of purpura fulminans, especially when it is presented with septicemia and disseminated intravascular coagulation. This highlights the importance of adding purpura fulminans to the differential diagnosis of skin necrosis over the nose, such as warfarin-induced skin necrosis, levamisole-contaminated cocaine-induced necrosis, and cryoglobulinemia.

\section{Statement of Ethics}

The study was conducted ethically in accordance with the World Medical Association Declaration of Helsinki. Written, informed consent was taken from the patient's son for reporting this case.

\section{Disclosure Statement}

The authors have no conflicts of interest to declare. 


\section{Case Reports in Dermatology}

\section{Funding Sources}

There was no need for funding in this study.

\section{Author Contributions}

The manuscript is the original work of all authors. All authors made a significant contribution to this study. All authors have read and approved the final version of the manuscript.

\section{References}

1 Perera TB, Murphy-Lavoie HM. Purpura fulminans. StatPearls. StatPearls Publishing; 2019 [cited 2019 May 10]. Available from: http://www.ncbi.nlm.nih.gov/pubmed/30422460.

2 Lloyd TR, Bolte RG. Rhinocerebral mucormycosis in an infant with streptococcal sepsis and purpura fulminans. Pediatr Infect Dis. 1986;5(5):575-9.

3 Har-El G, Nash M, Chin NW, Meltzer CJ, Weiss MH. Purpura fulminans of the head and neck. Otolaryngol Head Neck Surg. 1990;103(4):660-3.

4 Duteille F, Perrot P, Pannier M. Suitable age for nasal reconstruction after subtotal amputation in a child, with respect to a case involving purpura fulminans. J Pediatr Surg. 2006 Sep;41(9):1616-9.

5 Urushidate S, Yokoi K, Higuma Y, Mikami M, Watanabe Y, Saito M, et al. Nose and upper lip reconstruction for purpura fulminans. J Plast Reconstr Aesthet Surg. 2012 Feb;65(2):252-5.

6 Eng PC, Bryant C, Jackson S. A case of infectious purpura fulminans: an unusual organism and method of diagnosis. Eur J Case Rep Intern Med. 2014 Apr;1(1):13.

7 Shenoy R, Nanjappa S, Eaton K, Prieto-Granada C, Messina JL, Greene JN. Purpura fulminans. Infect Dis Clin Pract. 2017 Mar;25(2):100-4.

8 Moon SM, Hong YS, Lee DS, Chung CR. Purpura fulminans on the nose with septic abortion. Intensive Care Med. 2015 Jun;41(6):1122. 


\section{Case Reports in Dermatology}
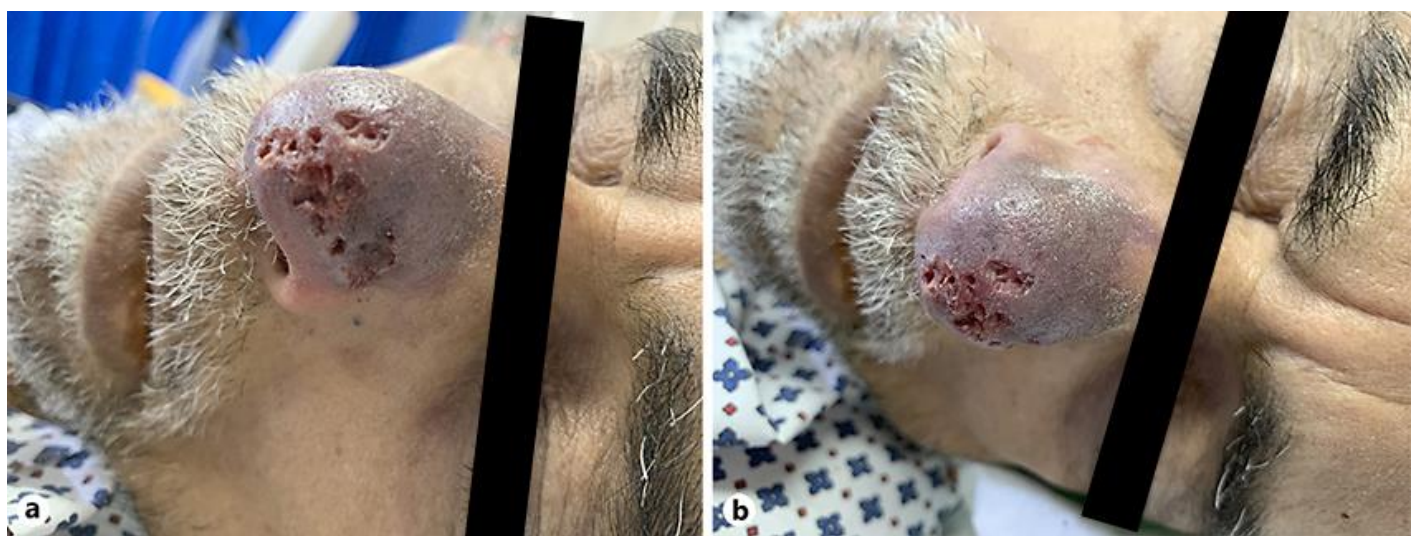

Fig. 1. a, b On the first day, nonblanching violaceous ecchymosis was seen with localized central early skin necrosis on the tip of the nose.


Fig. 2. a, b On the second day, sharply delineated full-thickness necrosis was seen over the patient's entire nasal region. 
Table 1. Laboratory values

\begin{tabular}{|c|c|c|c|}
\hline & Results & Reference range & Comments \\
\hline \multicolumn{4}{|l|}{ CBC (complete blood count) } \\
\hline Hemoglobin & 70 & $130-170 \mathrm{~g} / \mathrm{L}$ & Low \\
\hline Red blood cell & 2.72 & $4.5-5.5 \times 10^{12} / \mathrm{L}$ & Low \\
\hline Hematocrit & 0.22 & $0.4-0.5 \mathrm{~L} / \mathrm{L}$ & Low \\
\hline Mean corpuscular volume & 80.5 & 83-101 FI & Low \\
\hline $\mathrm{MCH}$ & 24.3 & $27-32 \mathrm{pg}$ & Low \\
\hline MCHC & 301 & $315-345 \mathrm{~g} / \mathrm{L}$ & Low \\
\hline RDW-CV & 20.9 & $11.6-14 \%$ & High \\
\hline RDW-SD & 59.5 & $39-46$ FI & High \\
\hline Normoblasts (relative) & 17.8 & $0-0 \%$ & High \\
\hline Normoblasts (absolute) & 4 & $0 \times 10^{3} / \mathrm{IU}$ & High \\
\hline WBC (total) & 22.44 & $4-11 \times 10^{9} / \mathrm{L}$ & High \\
\hline Platelets count & 12 & $150-400 \times 10^{9} / \mathrm{L}$ & Low \\
\hline \multicolumn{4}{|l|}{ Coagulation profile } \\
\hline PT (prothrombin time) & 32.1 & $11-16 \mathrm{~s}$ & Prolonged \\
\hline PTT (partial thromboplastin time) & 81.4 & $26-39 s$ & Prolonged \\
\hline INR (international normalized ratio) & 2.72 & $0.8-1.2$ & High \\
\hline D-dimer & 5.3 & $0-0.55 \mathrm{mg} / \mathrm{L}$ & Elevated \\
\hline Fibrinogen & 0.7 & $1.8-3.5 \mathrm{~g} / \mathrm{L}$ & Low \\
\hline
\end{tabular}


Alsharif et al.: Uncommon Location of Purpura Fulminans

Table 2. Summary of the cases reported in the literature with purpura fulminans over the nose

\begin{tabular}{|c|c|c|c|c|c|c|c|}
\hline Title & Authors & $\begin{array}{l}\text { Year c } \\
\text { cation }\end{array}$ & - Age & Sex & $\begin{array}{l}\text { Site of purpura ful- } \\
\text { minans }\end{array}$ & Pathogenesis & Ref. \\
\hline $\begin{array}{l}\text { Rhinocerebral mucormycosis in an } \\
\text { infant with streptococcal sepsis and } \\
\text { purpura fulminans }\end{array}$ & Lloyd TR, Bolte RG & 1986 & $2 \mathrm{M}$ & Male & $\begin{array}{l}\text { Extremities, and } \\
\text { nose }\end{array}$ & $\begin{array}{l}\text { Streptococcal } \\
\text { sepsis }\end{array}$ & 2 \\
\hline $\begin{array}{l}\text { Purpura fulminans of the head and } \\
\text { neck }\end{array}$ & $\begin{array}{l}\text { Har-El G, Nash M, Chin } \\
\text { NW, Meltzer CJ, } \\
\text { Weiss MH }\end{array}$ & 1990 & $34 \mathrm{Y}$ & Male & $\begin{array}{l}\text { Lower extremities, } \\
\text { nose, lips and ear }\end{array}$ & $\begin{array}{l}\text { Pneumococcal } \\
\text { sepsis }\end{array}$ & 3 \\
\hline $\begin{array}{l}\text { Suitable age for nasal reconstruc- } \\
\text { tion after subtotal amputation in a } \\
\text { child, with respect to a case involv- } \\
\text { ing purpura fulminans }\end{array}$ & $\begin{array}{l}\text { Duteille F, Perrot P, } \\
\text { Pannier M }\end{array}$ & 2006 & $3 Y$ & Male & Hands, feet, and nose & $\begin{array}{l}\text { Meningococcus } \\
\text { sepsis }\end{array}$ & 4 \\
\hline $\begin{array}{l}\text { Nose and upper lip reconstruction } \\
\text { for purpura fulminans }\end{array}$ & $\begin{array}{l}\text { Urushidate S, Yokoi K, } \\
\text { Higuma Y, Mikami M, } \\
\text { Watanabe Y, Saito M, } \\
\text { et al. }\end{array}$ & 2012 & $48 \mathrm{Y}$ & Male & $\begin{array}{l}\text { Nose, upper lip, } \\
\text { palms and lower } \\
\text { limbs }\end{array}$ & $\begin{array}{l}\text { Klebsiella } \\
\text { pneumoniae }\end{array}$ & 5 \\
\hline $\begin{array}{l}\text { A case of infectious purpura fulmi- } \\
\text { nans: an unusual organism and } \\
\text { method of diagnosis }\end{array}$ & $\begin{array}{l}\text { Eng PC, Bryant C, } \\
\text { Jackson S }\end{array}$ & 2014 & $66 \mathrm{Y}$ & Male & $\begin{array}{l}\text { Thorax, abdomen, } \\
\text { digits, lower limbs } \\
\text { and nose tip }\end{array}$ & $\begin{array}{l}\text { Capnocytophaga } \\
\text { canimorsus } \\
\text { septicemia }\end{array}$ & 6 \\
\hline $\begin{array}{l}\text { Purpura fulminans on the nose with } \\
\text { septic abortion }\end{array}$ & $\begin{array}{l}\text { Moon SM, Hong YS, } \\
\text { Lee DS, Chung CR }\end{array}$ & 2015 & $34 \mathrm{Y}$ & Female & Nose & Escherichia coli & 8 \\
\hline Purpura fulminans & $\begin{array}{l}\text { Shenoy R, Nanjappa S, } \\
\text { Eaton K, Prieto-Granada } \\
\text { C, Messina JL, Greene JN }\end{array}$ & 2017 & $78 \mathrm{Y}$ & Female & $\begin{array}{l}\text { Abdomen, extremi- } \\
\text { ties, nose, and cheek }\end{array}$ & $\begin{array}{l}\text { Paraneoplastic } \\
\text { syndrome in a } \\
\text { patient with } \\
\text { mesothelioma }\end{array}$ & 7 \\
\hline Present case & $\begin{array}{l}\text { Alsharif, Al-Omair, } \\
\text { Andijani }\end{array}$ & 2019 & $75 \mathrm{Y}$ & Male & Nose & MRSA & \\
\hline
\end{tabular}

